\title{
Correction to: Engaging Practitioners as Inquirers: Co-constructing Visions for Music Teacher Education in Nepal
}

\author{
Danielle Shannon Treacy
}

\section{Correction to:}

\section{Chapter 13 in: H. Westerlund et al. (eds.), Visions for Intercultural Music Teacher Education, Landscapes: the Arts, Aesthetics, and Education 26, https://doi.org/10.1007/978-3-030-21029-8_13}

An earlier version of the book has been published with incorrect citation for the quotation "An organized field of social practices, a form of work..." as (Appadurai 2006, 31) on page 198. The citation has now been corrected as follows:

An organized field of social practices, a form of work (in the sense of both labor and culturally organized practice), and a form of negotiation between sites of agency (individuals) and globally defined fields of possibility. (Appadurai 1996, 31) 